\title{
Research Paper: Identifying Strategic Priorities for the Sustainable Development of Rural Areas Based on Local Community Planning
}

\author{
Mahmoud Jomehpour ${ }^{1^{*}}$
}

1. Professor, Department of Social Planning, Faculty of Social Sciences, Allameh Tabataba'i University, Tehran, Iran.

Citation: Jomehpour, M. (2017). Identifying Strategic Priorities for the Sustainable Development of Rural Areas Based on Local Community Planning. Journal of Sustainable Rural Development, 1(2), 161-170. https://doi.org/10.29252/jsrd.01.02.161

https://doi.org/10.29252/jsrd.01.02.161

Article info:

Received: 10 Jun. 2017

Accepted: 25 Sep. 2017

\section{Keywords:}

Rural community of Iran, Participatory rapid appraisal, Participation planning methods, Local planning, Endogenous knowledge, Sustainable livelihood development

\section{ABSTRACT}

Purpose: Iran has about 60000 villages with a wide variety of issues and problems. The aim of this study was to understand the real situation, development needs, and priorities of rural communities through local community participation in the planning process. The main questions of this research are: What are the most important issues of the rural communities and the main priorities for their rural development of the local community?; What are the strategies for the development of rural communities and resolving their problems?

Methods: The statistical population comprised all rural areas of Iran. The research method was Participatory Rapid Appraisal (PRA) meetings conducted in 120 villages in different provinces of Iran, representing random distribution of the rural communities. In addition to group meetings, field observation, completing questionnaires, and holding interviews with representatives of local community groups have been conducted. Eventually, the obtained data have been prioritized through a questionnaire with 20 experts in this field.

Results: The results show that all rural community issues can be grouped into 5 and the most important issues are related to the management problems of the local community, in other words, the role of government institutions as the main authority, engaging in a centralized and top-down development programs.

Conclusion: Achieving sustainable development of rural areas and local communities, is only possible through the establishment of a system of governance based on local community planning as they are the main beneficiaries of development programs.

\section{Introduction}

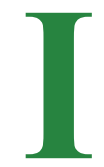

$t$ is empirically proved that without improving the situation of poor and deprived rural society, any development plan could end up with serious problems to achieve its objectives. With regard to the necessity and importance of rural development, various strategies have been proposed to achieve rural development in the recent decades. One of the strategies to improve the quality of life in the ru-

* Corresponding Author:

Mahmoud Jomehpour, PhD

Address: Department of Social Planning, Faculty of Social Sciences, Allameh Tabataba ’i University, Tehran, Iran.

Tel: +98 (912) 2203429

E-mail:jomehpoor@atu.ac.ir 
ral areas and decrease the gap between urban and rural society, is to really understand them and contribute local society in planning. Any strategic plan for sustainable development of rural societies involves comprehensive approach and integrated attitude towards rural development as a part of social, economic, spatial and political system of national territory.

\section{Description of problem}

In the era of information and communications, many social, economic, and cultural relations, as well as organizations and institutions have been transformed. Rural society as a major part of national society, which still accommodate one third of country population, is not an exception. Acquiring knowledge, policy making, and planning in the transformed or being transformed society require changes in our approach towards that society, and old stereotype solutions could not solve new problems. As Earl Babbie mentioned in the preface of his book, "if we want to control the issues of hunger, poverty, crimes, pollution and all complications affecting modern society, we need a new attitude." (Babbie, 2014). Change in attitude and method of analyzing the problems is the prerequisite to solve the problems of modern society. In this regard, the researchers have changed their methods for achieving their objectives and let all members of society to participate and involve in the process of research and understanding the problem.

In many planning activities, including rural development projects, several fundamental challenges should be addressed. These are as follows: The data and information used for research do not reflect the reality of target society; Researcher does not have a proper understanding of target society, and is affected by the biased judgments; and the tools and methods of data collection or information analysis do not represent the problems as they really are.

One of the ways to avoid such hindrances is to let the target society be know the research problem. In the process of policy making, decision making, and planning for development of rural society, the important questions are detecting the most important problems of our rural society, and their priorities. Obviously, the answers to these questions could change considerably the course of policy making and planning. Participation planning methods in which the individuals and all classes of target society are involved in the process of research, decision making and planning, is one of the methods of improvement of policy making and planning based on the real flow of sociobiology that increase the chance of realizing the targets of the projects.

Necessity and importance of participation planning and compilation of strategy of rural development

Participation planning requires several key components that are as follows: Accurate knowledge of existing situation of rural society and pattern of needs of this society; Recognition of priority of issues and problems of rural society based on the real needs of society; Letting participation of rural society in the process of review of issues and determination of priorities of rural planning; Encouraging people's participation in the decision makings and taking practical measures; Making an equitable and fair decision with participation of villagers and authentication of rural society through letting their participation in the process of research and decision making; and achieving sustainable rural development through implementing participation process and persuading all members of society to contribute in all steps of planning from preparation to implementation and evaluation of plans.

\section{General objective of research}

The general objective of this research is to understand the current situation, requirements and priorities of development of rural society through inviting rural people to participate in the process of planning.

\section{Questions of research}

These research questions are as follows: What are the most important issues and problems of rural society from the viewpoint of local community?; What are the most important priorities of rural development in the viewpoint of rural society?; What is the appropriate strategy for rural development and solutions of rural issues of country?

\section{Literature Review}

The concept of participation planning is a new approach proposed for better realization of the objectives, planning, and achieving the more appropriate results. Focusing on participation could be deemed concordant with democratization of societies and establishment of NGOs as a step toward autonomy of local communities. However, one of the reasons of focusing on participation as a pattern of development and planning is failure of top-down and authoritative development ideas.

The attitude of development of local community considers participation as a way for capacity building at the 
level of local community, and believes that the individuals of society should control, intervene and affect their environment in the process of social capacity building. Numerous studies (Crichton, 1996) indicate that local residents are more aware of their problems than the nonlocal experts, so they better understand the conditions for solving their problems. This principle is the basis of participation planning methods like rural participation evaluation stressing on local people's better understanding of their situation compared with the non-local experts.

The new strategies of development assume good governorship as one of the necessities of local and regional sustainable development. The strategy which includes two concepts of "enabling" and "participation" (Sarrafi, 2004:73-98; Stenseke, 2009:214-33). Participation is one of the basic principles of governorship, and rural governorship means realization of decisions and requests of rural people for their benefits (Azimi \& Eftekhari, 2014:22). Participation of local society is a solution for passing from government to governorship and letting local people be involved in the process of policy making, preparation, and implementation of plans and movement from top-down centralized to bottom-up decentralized decision making (Jomehpour, 2016). The main objective in participation planning is movement towards lower involvement of governments and stronger pattern of participation development. Participatory approaches and methods can explore issues in relation to human rights. They can also generate numbers as alternatives or complements to questionnaires. The horizons for better development practice through levelling and reversing power relations is immense. In a good participatory practice, innovation is a way of being. The real challenge in participation is to enable those who are most marginalized, powerless, and poor achieve a better life for themselves (Chambers, 2012).

The researchers like John Forester (1989) found that planners should meet various classes of people with different ideas and networks, and share information and communicate with them. In other words, this new theoretical approach stresses on public participation and continuous communication between the planners, citizens, developers, governmental authorities and other groups as the main mechanisms through which the objectives are realized and people are trained. Although as Patsy Healey discussed, for being practical and effective, this method should be based on how knowledge pattern and social communication are developed. This approach is somehow overlap with the approaches of institutionalism and social learning.
In this framework, the main task of planners is to listen to the people and make the different ideas closer and compatible. Instead of just giving technical and specialized comments, the planners should attempt to present accurate information to the beneficiary groups in the planning process and close the different approaches together. Leadership of planning process does not merely imply gathering beneficiary groups together. Rather, it should develop a consensus among them and assuring people that all various groups, despite of their economic, political and social differences, could confiscate planning process in their own favor.

Planning in local levels is an appropriate place for using communicative and participation planning methods. In the rural area or local society, it is possible to let beneficiaries be involved directly in the process of participation through congregational methods like group meetings or nonofficial organizations. Finally, the experience of development has proved that any developmental method in which the actors of local society are really involved in the process of development, could result in a more sustainable and durable development. Their more extensive insights and participation together with mobilization of local human resources, target oriented and mutual interaction among the official, nonofficial and local traditional organizations, could result in formation of a selfsufficient and endogenous development process. In other words, local people first need to be seen and recognized, and then, to be supported for fulfilment of their needs deserved for a high quality human life. In this case, a synergic relation could emerge among the politicians, decision makers, developers and local society. Nowadays, the final version of sustainable development is endogenous and self-sufficient human-based development together with creation of equality i.e., equal opportunities.

In the present condition of our country which strategically requires self-sufficiency, it seems that development of rural areas in the framework of participation and local planning and taking into account regional differences could lead us to the objectives of endogenous development and sustainable economy and livelihood. Participation planning method in the framework of regional rural development is development with people and for people, which could result in alignment and synergy of different sources towards sustainable development.

\section{Methodology}

The main focus of this research is participation planning methods and holding rapid appraisal meetings with rural people in various parts of country. The random dis- 


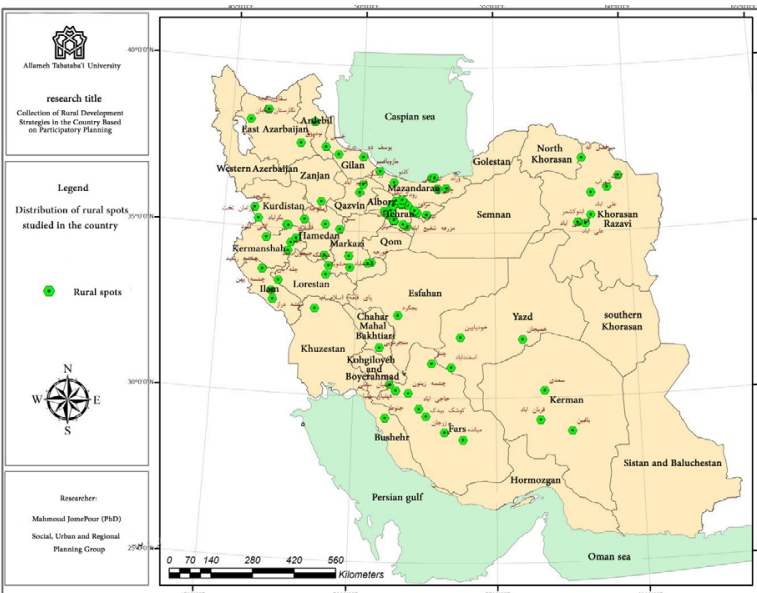

Figure 1. Distribution of selected villages for the study

tribution of villages throughout the country makes the whole meetings be held in a four years period. Considering variety of individuals holding participation meetings, they cover a wide range of participation methods, including group discussion, deep interview, rapid appraisal, participation evaluation, and training. In the prevailing form of meetings, participation discussion had a cognitive aspect and was held for recognition of issues and problems and their prioritization. In addition to holding group meetings, field observation, completion of village questionnaire, interview with the trustees, members of village council, governors of villages, the elders and representatives of various groups were performed, providing a useful data bank from an extensive spectrum of villages that could be valuable for various further studies.

\section{Description of studied sample}

Totally, the studied villages included 120 villages, distributed in 25 provinces. Tehran Province with 24 vil- lages had the most share in the sample due to accessibility of villages. Since only 6 provinces of South Khorasan, Sistan and Baluchistan, Golestan, West Azerbaijan, Kohgiluyeh and Boyer-Ahmad and Hormozgan did not have any representative in this distribution, and considering similarity of absent provinces in the study with the present ones, we could assume the studied villages as the representative of all villages of our country (Table 1). Figure 1 shows distribution of studied villages throughout the country.

The average number of individuals present in the participation rural appraisal and group discussions based on the meetings is 17.45 , the average number of meetings held in each village 1.2, and duration of holding meetings was about 3 hours. On this basis, totally about 1870 persons have participated in the meetings of participatory rural appraisal all over the, which by adding those who have been interviewed or completed questionnaires, it amounts up to about 2000 persons (Figure 1).

Among the studied villages, the average number of households in the villages was 261 , the biggest village has 1665 households, and the smallest village has 30 households. The average population of sample villages is 814 persons, and the average number of men and women are respectively 442.6 and 429.2. The sex proportion in the studied villages has been about 103 .

Situation of availability and level of welfare in the studied rural society

In this step, to obtain a clearer perspective of situation of studied villages, they were classified with respect to welfare availability based on a series of welfare, training, hygienic and medicinal, cultural, infrastructural and sub-

Table 1. Demographic characteristics of the sample villages

\begin{tabular}{|c|c|c|c|c|c|c|c|}
\hline \multirow{2}{*}{$\begin{array}{l}\text { Demographic } \\
\text { Characteristics }\end{array}$} & \multirow{2}{*}{ Household Number } & \multicolumn{3}{|c|}{ Population } & \multirow{2}{*}{$\begin{array}{c}\text { Men } \\
\text { Percentage }\end{array}$} & \multirow{2}{*}{$\begin{array}{c}\text { Women } \\
\text { Percentage }\end{array}$} & \multirow{2}{*}{$\begin{array}{c}\text { The Sex } \\
\text { Ratio }\end{array}$} \\
\hline & & Total & Men & Women & & & \\
\hline Total population & 24015 & 100256 & 50869 & 49360 & 51 & 49 & 103 \\
\hline Average & 261 & 814 & 442.6 & 429.2 & - & - & - \\
\hline The highest & 1665 & 6009 & 3147 & 2862 & - & - & - \\
\hline The lowest & 30 & 92 & - & - & - & - & - \\
\hline Village frequency & 107 & 107 & - & - & - & - & - \\
\hline
\end{tabular}


Table 2. Selected service indicators to determine the level of welfare of the sample villages

\begin{tabular}{|c|c|}
\hline Services & Service Indicators \\
\hline Educational services & 15 Educational indicators including primary school, middle school, high school and so on \\
\hline Health services & $\begin{array}{l}12 \text { Health indicators including health room, public hospital, pharmacies, physician, dentist, } \\
\text { and so on }\end{array}$ \\
\hline Cultural and welfare services & $\begin{array}{l}6 \text { Cultural and welfare indicators including rural parks, public libraries, sports grounds, public } \\
\text { Internet access, and so on }\end{array}$ \\
\hline $\begin{array}{l}\text { Administrative and organizational } \\
\text { services }\end{array}$ & $\begin{array}{l}8 \text { Administrative and organizational indicators including agriculture service center, rural } \\
\text { cooperative, and so on }\end{array}$ \\
\hline $\begin{array}{l}\text { Infrastructural and foundational } \\
\text { services }\end{array}$ & $\begin{array}{l}10 \text { Infrastructural and foundational indicators including national network electricity, diesel } \\
\text { engine, new energy (solar, wind, etc.), gas pipelines, water pipelines, and so on }\end{array}$ \\
\hline Business and welfare services & $\begin{array}{c}11 \text { Business and welfare indicators including banks, repair agricultural machinery, gas station, } \\
\text { cooperative store, and so on }\end{array}$ \\
\hline $\begin{array}{l}\text { Information and Communications } \\
\text { Technology Services }\end{array}$ & $\begin{array}{l}6 \text { Information and communications technology indicators including access to public trans- } \\
\text { port, access to the railway station, office of the Information and Communication Technology } \\
\text { (ICT) in rural areas and so on }\end{array}$ \\
\hline
\end{tabular}

- JSRD

structural, administrative, commercial, communicational and information technology criteria. This study aimed to analyze the relationship between the welfare level of villages and situation and priority of villages' problems based on field assessments and holding PRA meetings.

For this purpose, using statistical data of villages in 2011 and 2003 agricultural general census, a series of indexes were selected and after several steps and deletion of a number of them, finally 69 indexes were used for assessment of availability level. Of this indexes, 15 indexes are related to training services, 12 indexes to sanitary and medicinal services, 6 indexes to welfare cultural services, 8 indexes to the organizational and administrative indexes, 10 indexes to the infrastructural and sub-structural services, 11 indexes to the commercial welfare services, and 6 indexes to the commu- nication services and communication technologies. Table 2 presents major groups of services and selected indexes.

Level of development of rural areas of our country separated by provinces

After description of service indexes and level of access to services and welfare facilities and study of their spatial distribution (Jomehpour, 2005), taxonomy model was used for displaying level of development of rural areas in different provinces. After several steps of calculation with various series of indexes, finally 23 indexes which were more influential based on the available statistics were selected. Table 3 presents final indexes used for the assessment of development level of provinces. Figure 2 shows the classification of rural region development in the provinces.

Table 3. Classification based on the level of development of rural regions in the provinces

\begin{tabular}{|c|c|c|}
\hline Provinces & Development Index Range & $\begin{array}{c}\text { Rural Region Development } \\
\text { Level }\end{array}$ \\
\hline Golestan, Hamadan, Mazandaran, Gilan, Booshehr, Tehran, Isfahan & $0.45-0.65$ & Fully developed regions \\
\hline $\begin{array}{l}\text { Chaharmahal and Bakhtiari, Ghazvin, North Khorasan, Markazi, } \\
\text { Zanjan, East Azerbaijan, Ardabil, llam, West Azerbaijan, Ghom, } \\
\text { Kermanshah }\end{array}$ & $0.651-0.75$ & Developed regions \\
\hline Kurdistan, Hormozgan, Khorasan Razavi, Lorestan, Fars & $0.751-0.85$ & Relatively developed \\
\hline Kohgiluyeh and Boyer-Ahmad, Khuzestan, Yazd, Semnan & $0.851-0.90$ & Relatively underdeveloped \\
\hline South Khorasan, Kerman, Sistan and Baluchistan & $0.91>$ & Under developed \\
\hline
\end{tabular}


Table 4. The total frequency of discussed issues selected studied villages

\begin{tabular}{|c|c|c|c|c|c|c|c|c|c|c|c|}
\hline & \multirow[t]{2}{*}{$\begin{array}{r}\text { Main Issue } \\
\text { Selected } \\
\text { Village }\end{array}$} & \multicolumn{2}{|c|}{$\begin{array}{l}\text { Water Issues (Man- } \\
\text { agement, Exploit } \\
\text { and Access) and the } \\
\text { Environment } \\
\text { (Final Score) }\end{array}$} & \multicolumn{2}{|c|}{$\begin{array}{l}\text { Issues Related to } \\
\text { Agricultural Produc- } \\
\text { tion, Livestock and } \\
\text { the Exploitation of } \\
\text { the Land } \\
\text { (Final Score) }\end{array}$} & \multicolumn{2}{|c|}{$\begin{array}{c}\text { Social and } \\
\text { Economic Issues } \\
\text { (Employment, } \\
\text { Income, Migration) } \\
\text { (Final Score) }\end{array}$} & \multicolumn{2}{|c|}{$\begin{array}{l}\text { Management } \\
\text { Issues, Lack of } \\
\text { Government } \\
\text { Oversight, the Lack } \\
\text { of State Funds } \\
\text { (Final Score) }\end{array}$} & \multicolumn{2}{|c|}{$\begin{array}{l}\text { Issues of Welfare, } \\
\text { Services, Con- } \\
\text { struction } \\
\text { (Final Score) }\end{array}$} \\
\hline & & Frequency & Ratio & Frequency & Ratio & Frequency & Ratio & Frequency & Ratio & Frequency & Ratio \\
\hline 1 & Bidak & 52 & 0.115 & 95 & 0.211 & 82 & 0.184 & 114 & 0.252 & 108 & 0.241 \\
\hline 2 & Haftkadeh & 30 & 0.058 & 45 & 0.087 & 45 & 0.087 & 113 & 0.217 & 68 & 0.13 \\
\hline 3 & Kamalolmolk & 26 & 0.166 & 35 & 0.224 & 42 & 0.269 & 37 & 0.218 & 16 & 0.103 \\
\hline 4 & $\begin{array}{c}\text { Korheh } \\
\text { and varin }\end{array}$ & 90 & 0.136 & 75 & 0.071 & 113 & 0.152 & 193 & 0.234 & 192 & 0.304 \\
\hline 5 & Chenar & 96 & 0.128 & 178 & 0.198 & 252 & 0.168 & 232 & 0.258 & 225 & 0.25 \\
\hline 6 & $\begin{array}{c}\text { Zarnan } \\
\text { paeen }\end{array}$ & 32 & 0.15 & 23 & 0.108 & 47 & 0.221 & 82 & 0,384 & 29 & 0.134 \\
\hline 7 & Maloojeh & 8 & 0.036 & 35 & 0.154 & 35 & 0.153 & 88 & 0.277 & 61 & 0.258 \\
\hline 8 & Kood sofla & 54 & 0.15 & 86 & 0.239 & 86 & 0.239 & 82 & 0.228 & 51 & 0.141 \\
\hline 9 & Yousofdeh & 7 & 0.031 & 68 & 0.305 & 65 & 0.292 & 52 & 0.232 & 32 & 0.142 \\
\hline 10 & Paghlaeh & 34 & 0.221 & 28 & 0.182 & 20 & 0.13 & 21 & 0.136 & 49 & 0.329 \\
\hline
\end{tabular}

\section{Findings}

Description and analysis of quality findings, participation rural appraisal

Considering the high number of studied samples, we tried to prepare 10 Participation Rural Appraisal (PRA) reports based on the variety of villages their geographi-

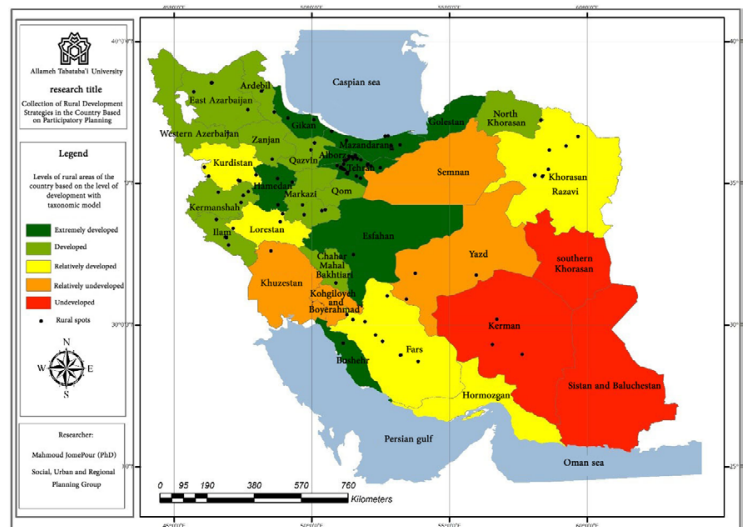

JSRD

Figure 2. Classification of provinces based on the level of rural regions development cal variation, and subsequently, analyze them as per comments of experts and quantitative methods.

PRA meeting starts after gathering of villagers in the location of holding meeting and explaining the purpose of holding discussion and then asking the question that "What are the issues and problems of your village?" The items mentioned by the participants were registered before all attendees, and then, their importance and prioritization were discussed. All items were discussed by direct participation of all attendees and came finally into some agreement. After discussion of issues and problems, in the second step of implementation of PRA, the issues were classified by the participants, and in the next step of group discussion, the issues were prioritized. Table 4 presents the result of classification and prioritization based on the frequency of discussed issues in each group (Figure 3).

\section{Analysis of findings of experts' questionnaires}

One of the criticisms to PRA method is that like many top-down methods, this method lacks required scientific stability and authenticity. Outcomes of these meetings 
Table 5. The importance and priority of issues of selected villages based on QSPM model

\begin{tabular}{|c|c|c|c|c|c|c|c|}
\hline & Selected Village & $\begin{array}{l}\text { Water Issues } \\
\text { (Management, } \\
\text { Exploit and } \\
\text { Access) and the } \\
\text { Environment } \\
\text { (Final Score) }\end{array}$ & $\begin{array}{l}\text { Issues Related } \\
\text { to Agricultural } \\
\text { Production, } \\
\text { Livestock and } \\
\text { the Exploita- } \\
\text { tion of the Land } \\
\text { (Final Score) }\end{array}$ & $\begin{array}{c}\text { Social and } \\
\text { Economic Is- } \\
\text { sues (Employ- } \\
\text { ment, Income, } \\
\text { Migration) } \\
\text { (Final Score) }\end{array}$ & $\begin{array}{l}\text { Management } \\
\text { issues, Lack of } \\
\text { Government } \\
\text { Oversight, the } \\
\text { Lack of State } \\
\text { Funds (Final } \\
\text { Score) }\end{array}$ & $\begin{array}{l}\text { Issues of } \\
\text { Welfare, } \\
\text { Services, } \\
\text { Construc- } \\
\text { tion (Final } \\
\text { Score) }\end{array}$ & Average \\
\hline 1 & Bidak & 4.573 & 6.779 & 4.703 & 7.64 & 7 & 6.14 \\
\hline 2 & Haftkadeh & 2.001 & 17.24 & 3.306 & 6.983 & 4.233 & 6.75 \\
\hline 3 & Kamalolmolk & 6.557 & 7.657 & 10.286 & 8.636 & 3.824 & 7.39 \\
\hline 4 & Korheh and Varin & 5.25 & 2.474 & 6.345 & 9.613 & 8.95 & 7.39 \\
\hline 5 & Chenar & 5.28 & 6.204 & 5.322 & 7.795 & 7.536 & 6.53 \\
\hline 6 & Zarnan paeen & 5.478 & 3.639 & 7.978 & 11.628 & 4.2 & 6.48 \\
\hline 7 & Maloojeh & 1.53 & 5.088 & 5.447 & 13,542 & 8.47 & 6.5 \\
\hline 8 & Kood sofla & 6.084 & 8.51 & 8.744 & 7.276 & 4.86 & 6.7 \\
\hline 9 & Yousofdeh & 1.271 & 10.417 & 11.744 & 8.062 & 4.54 & 7 \\
\hline 10 & Paghlaeh & 8.385 & 6.344 & 4.55 & 4.388 & 10.93 & 7.16 \\
\hline & Average & 4.754 & 6.096 & 7.161 & 8.91 & 7.07 & \\
\hline
\end{tabular}

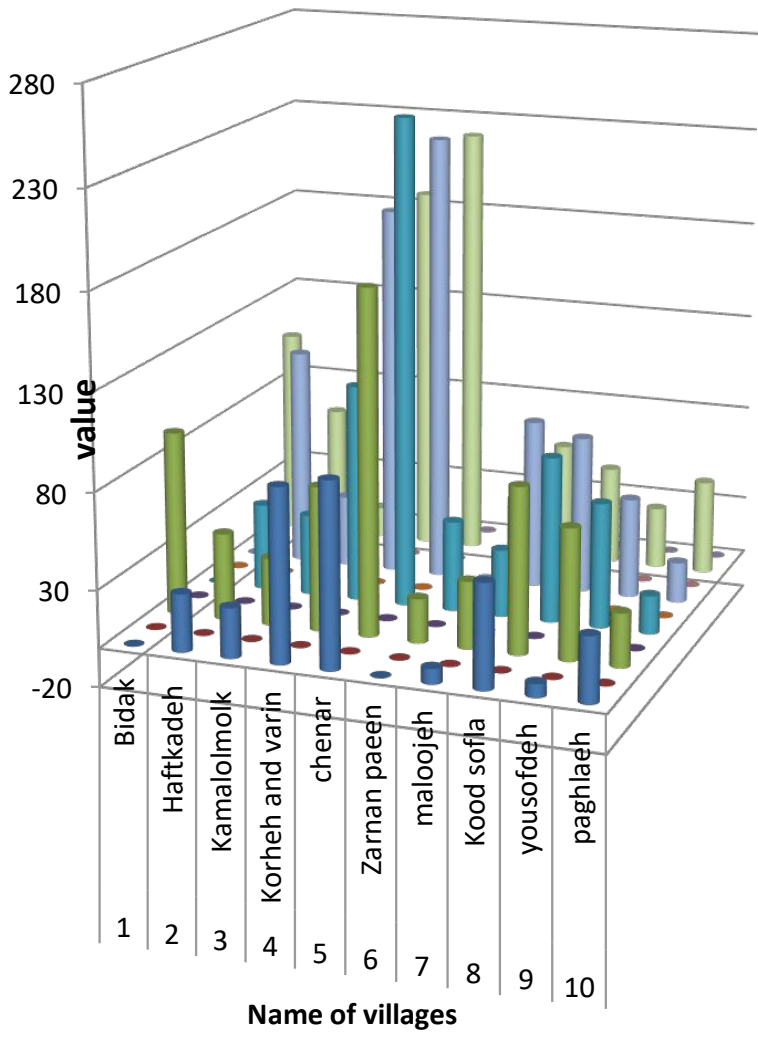

Water issues (management, exploit and access) and the environment (Final Score) Frequency

Water issues (management exploit and access) and the environment (Final Score) Ratio

- Issues related to agricultural production, livestock and the exploitation of the land (the final score) Frequency

- Issues related to agricultural production, livestock and the exploitation of the land (the final score) Ratio

- Social and economic issues (employment, income, migration) (Final Score) Frequency

- Social and economic issues (employment, income, migration) (Final Score) Ratio

Figure 3. Total frequency based on study participants 


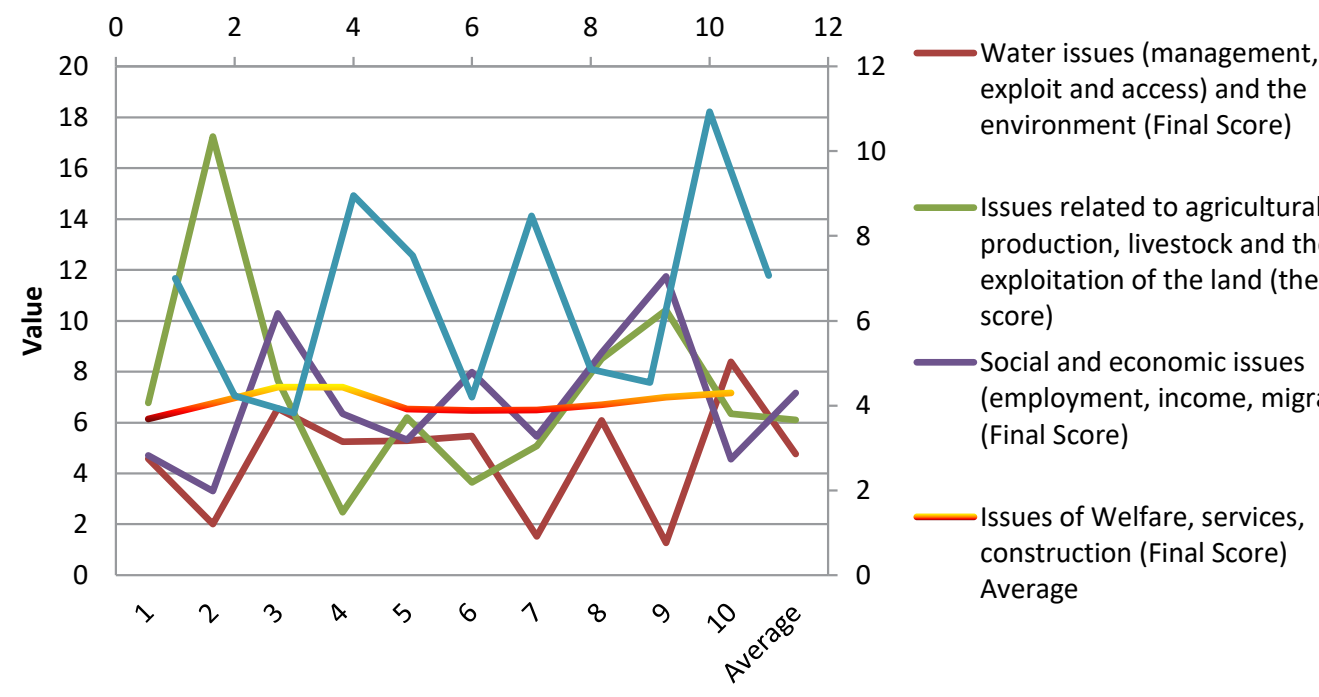

Figure 4. The importance and priority of issues in selected villages

depend on the type and class of participants, the discussions could led to superficial and vulgar talks, one of the objections made to PRA methods. To avoid this objection, as it was already referred to in research methodology, the issues discussed in the PRA meeting should be studied and analyzed based on the expertise opinions. For this purpose, based on the classification of discussed issues and problems in PRA meeting, a five-factor Likert questionnaire was prepared and 15 senior experts of regional development planning were requested to fill the said questionnaires.

In this study, using Quantitative Strategic Planning Matrix (QSPM) model for prioritization of strategies, we attempted to grade and prioritize issues and discussions discussed in the PRA meetings. In this way, both the experts and local people are allowed to comment in the final analysis and provide the possibility of comparing ideas of experts, and finally achieve more comprehensive conclusion and accurate knowledge of the rural issues and problems and their priority through sharing their ideas based on the philosophy of participation planning. Table 5 presents the results of expertise questionnaire for determination of coefficient of importance and priority of issues and problems of selected villages based on QSPM model (Figure 4).

The remarkable point in presenting solutions is the role of government in solving problems. Almost in all presented solutions, people expect government to take the action. This expectation is partly due to historical role of the government in centralized and top-down planning projects and based on this assumption, the villagers stress on the role of government. Since villagers had not participated in the development plans, they had almost no idea that the local society could solve many problems through partnership and cooperation. On the other hand, as it was already referred, many rural problems have external causes and one of them is the role and performance of governments. Therefore, level of issues and origin of their formation if participants in the meetings too have a proper understanding from them, requires intervention of external factor, that is, government. However, government's intervention should be changed from direct intervention and totalitarianism role to a facilitator and supporter one, and local society should directly participate in the whole process of development.

\section{Discussion}

The suitable strategy for planning development of our territory is participation strategies focused on the local society and involvement of all members of society in the process of development. Application of participation strategies results in: Obtaining detailed and realistic understanding of the needs, issues, and problems of society; Leaving the unreal findings and improper assumptions on development planning which is due to absence of participation of local society considering the extensive variety and complexity of issues of rural society; Attaining sustainable development plans and their objectives; Changing the state of the government from governance role to desirable governorship; Assigning the main role and task of development to people, and government adopts a facilitating role, resulting in increase in the performance efficiency of government; and authenticating the local 
society and increase of social capital and trust in the developmental plans and improving social responsibility.

\section{Acknowledgments}

This research was financally supported by Allame Tabataba'i University of Tehran.

\section{Conflict of Interest}

The authors declared no conflicts of interest.

\section{References}

Arnstein, S. R. (1969). A Ladder Of Citizen Participation Journal of the American Institute of Planners, 35(4), 216-224. doi:10.1080/01944366908977225

Azimi, J., \& Eftekhari, A. (2014). [Rural governance, sustainable development management (Persian)]. Tehran: SAMT.

Babbie, E. (2014). The Sociological Spirit 2: Critical Essays in a Critical Science. [M. H. Panahi, Persian trans.]. Tehran: Allameh Tabataba'i University.

Chambers, R. (2012). Revolutions in development inquiry. London Routledge.

Chambers, R. (2013). Ideas for development. London: Routledge.

Chambers, R., \& Conway, G. (1992). Sustainable rural livelihoods: practical concepts for the $21^{\text {st }}$ century. Brighton: Institute of Development Studies (UK).

Creighton, J. L. (1996). Involving citizens in community decision making: A guidebook. Washington D.C.: Program for Community Problem Solving.

Dent, D., Dubois, O., \& Dalal-Clayton, B. (2013). Rural planning in developing countries: Supporting natural resource management and sustainable livelihoods. London: Routledge.

Farrington, J., Ramasut, T., \& Walker, J. (2002) Sustainable Livelihoods Approaches in Urban Areas: General Lessons, with Illustrations from Indian Cases. London: Overseas Development Institute.

Forester, J. (1989). Planning in the Face of Power. Berkeley, Calif.: University of California Press.

Forester, J. (1993). Critical theory, public policy, and planning practice. Albany, NY: SUNY Press.

Habermas, J. (1990). Moral consciousness and communicative action. Cambridge, MA: MIT press.

Healey, P. (1997). Collaborative planning: Shaping places in fragmented societies. Vancouver: University of British Colombia Press.

Helling, A. (1998). Collaborative visioning: proceed with caution!: Results from evaluating Atlanta's Vision 2020 project.
Journal of the American Planning Association, 64(3), 335-349. doi $10.1080 / 01944369808975990$

Innes, J. E. (1995). Planning theory's emerging paradigm Communicative action and interactive practice. Journal of planning education and research, 14(3), 183-189. doi: $10.1177 / 0739456 \times 9501400307$

Jomehpour, M. (2005). [An introduction to rural development planning, approaches and methods (Persian)].Tehran: SAMT.

Jomehpour, M. (2016). [Participatory rural planning for strategically national rural development, Research Project (Persian)]. Tehran: Aallameh Tabataba'i University.

Mascarenhas, J. Shah, P., Joseph, S., Jayakaran, R., Devararam, J., Ramachandran, V., et al. (1991). Participatory rural appraisal. RRA Notes, 13. London: International Institute for Environment and Development (IIED).

Oakley, P. (1991). Projects with people: The practice of participation in rural development. London: International Labour Organization.

Sanoff, H. (2000). Community participation methods in design and planning. Hoboken, NJ: John Wiley \& Sons.

Sarrafi, mozafar (2004) People administrative system, providing context to rural community-development based on rural studies in Hamadan. High school in research and education of planning and management editor (pp 73-95), Hamadan, Iran.

Stenseke, M. (2009). Local participation in cultural landscape maintenance: Lessons from Sweden. Land Use Policy, 26(2) 214-223. doi:10.1016/j.landusepol.2008.01.005

Warburton, D. (2013). Community and sustainable development: Participation in the future. London: Routledge.

Westley, K., \& Sanderson, D. (2001). Participatory livelihoods assessment, Kosovo. Geneva: CARE International.

Wheeler, S. M. (2004). Planning for the sustainability of a vibrant balanced and ecological community [M. Jomehpour, \& Sh. Ahmadi, Persian trans.]. Tehran: Oloom-e Ejtema'i. 
